\title{
Irregular Immigration Status Impacts for Children in the USA
}

\author{
Susan Mapp ${ }^{1} \cdot$ Emily Hornung $^{1}$
}

Published online: 14 June 2016

C) Springer International Publishing 2016

\begin{abstract}
Recent public discourse has focused on immigration from Mexico and Central America, with debates about the impact of the undocumented population on the USA. However, less discussed is how the undocumented status of members of immigrant families - i.e., living in a mixed-status family or being unauthorized oneself-has far-reaching impacts on the well-being of children in the family. Ineligibility for services, as well as psychological impacts related to fears of deportation and the stigmatization of an immigrant identity, create numerous and at times unyielding barriers to physical health, educational success, and psycho-social well-being. Examining the current literature provides an overview of these impacts, how they violate children's rights, and their implications.
\end{abstract}

Keywords Mixed-status families · Immigration .

Undocumented immigration $\cdot$ Children

\section{Introduction}

It is currently estimated that approximately 11 million unauthorized immigrants live in the USA (Warren, 2016). Approximately two thirds are from Mexico and Central America; specifically about half are from Mexico, and $15 \%$ from countries in Central America (Passel \& Cohn, 2014). The Migration Policy Institute (MPI) states that 5.1 million children in the USA live with at least one unauthorized immigrant parent (Capps, Fix, \& Zong, 2016). The vast majority of

Susan Mapp

mapps@etown.edu

1 Elizabethtown College, One Alpha Drive, PA 17022, USA these children-4.1 million - are US citizens (Capps et al., 2016), creating "mixed-status" families which include one or more US citizen children or other authorized family members in addition to unauthorized family members, such as siblings, parents, or extended family members.

While laws regulating legal status are developed to punish the unauthorized, their multi-faceted consequences impact the entire family, regardless of status, reducing the economic, social, and emotional well-being of whole families and communities (Dreby, 2012, 2015; Waters \& Pineau, 2016). Unauthorized status in the US undermines protective social characteristics like familism, as well as social and financial capital, generating a continuum of barriers to generational integration into US society (Gleeson \& Gonzales, 2012). The widespread consequences of status limitations lawfully impose the inequality of the parent onto the child. Citizen children share with their families the risks and restrictions associated with lacking authorized status (Waters \& Pineau, 2016), becoming de facto unauthorized: learning how to be "illegal" in US society and experiencing the same stigma, poverty, and legal violence (Enriquez, 2015). As will be discussed, this legal and social environment violates children's rights in a variety of ways.

Citizen children in mixed-status families can suffer from many of the same stressors associated with immigration status as do unauthorized immigrant children and also experience the disadvantages which compromise healthy development. Research on mixed-status families has been limited, given the vulnerable nature of this population (Suárez-Orozco, Yoshikawa, Teranishi, \& Suárez-Orozco, 2011; Waters \& Pineau, 2016), but the impacts of immigration status on youth in mixed-status families are now becoming a focal point in the immigration debate (Viruell-Fuentes, Miranda, \& Abdulrahim, 2012). There are growing efforts to address an immigration system guided by policies restricting access to 
the necessities for the achievement of positive academic, health, and social outcomes, putting families and children at risk (Gonzales \& Chavez, 2012).

\section{Atmosphere of Immigrant Sentiment}

The current negative, anti-immigrant sentiment in the nation has resulted in increasingly harsh and restrictive national, state, and local laws that promote racial profiling and deputize local law enforcement as immigration officers (Abrego \& Manjívar 2011; Alvarez Gutiérrez, 2013). Much of this debate has focused on those born in Mexico or Central America due to their relatively high numbers, and thus is the focus of this paper. Federal efforts to curb immigration into the USA, streamline the deportation process, and bar comprehensive immigration reforms favorable to unauthorized immigrants propagate discrimination and fear (Abrego \& Manjívar 2011), while states with such policies have fomented racial profiling and discrimination and increased deportations as compared with states without such policies (Androff et al., 2011; Arbona et al., 2010). These institutional factors of subjugation create an environment of legal violence which utilizes social controls such as prejudice, stereotyping, and discrimination to exert a punishing force on immigrants (Manjívar \& Abrego 2012).

Programs such as $287(\mathrm{~g})$ authorize jurisdictions to utilize state and local officers to enforce federal immigration law (Capps et al. 2011). The Secure Communities program (ended in 2014) mandated the collection of fingerprint data by ICE officials to track inmates' immigration status until their release and potential re-arrest and deputized local law enforcement as immigration officials (Donato \& Rodriguez, 2014; Flores, 2014). These programs likely contribute to Hispanic/Latino immigrants' mistrust of local law enforcement and their fear of utilizing public services such as police protection or emergency services (Rubio-Hernandez \& Ayón, 2016). This fear of law enforcement and public spaces disrupts the sense of protection and comfort in the community and increases the risks for unreported crime (Hardy et al., 2012). Distrust of public authorities, like police officers, decreases crime reporting among unauthorized immigrant populations (Dreby, 2012; Suárez-Orozco et al., 2011), leaving community members vulnerable to exploitation and crime.

Through criminalizing the actions of unauthorized immigrants by law, these policies and programs label and stigmatize these individuals as criminals (Abrego \& Manjívar 2011). Conflations of race and immigration status include authorized or citizen Latinos in environments of anti-immigrant sentiment and increase perceptions of all Latinos as unauthorized Mexicans, spreading stigma and hostility (Viruell-Fuentes et al., 2012). Microaggressions and subsequent stereotype threat experienced daily among peers, service providers, and other authorities perpetuate this hostile environment (RubioHernandez \& Ayón, 2016). Latino immigrant youth grow up fearing the deportation of themselves and their families (Dreby, 2012, 2015; Hagan et al., 2010), living in a context of antagonism towards both their ethnicity and their social identity.

This societal environment begets severe consequences for mixed-status families. The potential for deportation of a family member creates a state of constant hypervigilance and fear for an entire family, even if only one member is at risk (Chavez, Lopez, Englebrecht, \& Viramontez Anguiano, 2012; Dreby, 2015; Enriquez, 2015). Fear of deportation created by restrictive immigration legislation is the strongest contributing factor to reported stresses within and outside of the family for both authorized and unauthorized immigrants (Arbona et al., 2010).

Faced with limited options, parents try to insulate their children from these fears and risks, but at a great expense: families limit public exposure and disengage with the surrounding community and social supports (Hagan et al., 2010). Unauthorized children and children living in mixedstatus families are constantly pressured to remain under the radar, inconspicuous to authorities and community members, in order to protect family members from exposure (Goździak, 2014; Suárez-Orozco et al., 2011).

Parents in mixed-status families will avoid going out in public, even keeping children home from school, or refrain from engaging in certain activities or seeking help for employment, health, and language skills difficulties they encounter (Hagan et al., 2010; Hardy et al., 2012), further compounding the stress they experience related to immigration-related challenges. Fearing exposure from public authorities, immigrants underutilize social services, including those related to healthcare and nutrition, contributing to immigrant health disparities (Hardy et al., 2012). Lack of health and nutritional supports, as well as low-income family situations common among mixed-status families, reduce a child's physical and psychological well-being and contribute to lower education outcomes, all related to lower socioeconomic status in adulthood (Abrego \& Gonzales, 2010; Perreira \& Ornelas, 2011).

In a generalized climate of fear, families worry about being deported, of children being separated from them, of losing homes or jobs, and of suffering financial hardship (Hardy et al., 2012; Valdez et al. 2013). These daily fears and stressors of possible detention, deportation, and family separation experienced by parents are then transferred onto their children. Children are socialized to the cues and behaviors of their parents, adopting these survival strategies as well as the chronic stress inherent in using them, such as hypervigilance while driving, avoiding social services, or distrusting police (Dreby, 2015; Enriquez, 2015; Rubio-Hernandez \& Ayón, 2016).

To visually depict the impact of these policies on children, Dreby (2012) developed the "Deportation Pyramid." At the 
bottom, she places the Misunderstandings of Immigration in which children conflate immigration with illegality. Next is Fears About Family Stability, in which children fear for the safety of both themselves and their family members. She then places Short-term and then Long-term consequences, which can both include financial instability as well as emotional distress. At the peak of the pyramid is Family Dissolution.

Fears of deportation and separation are well-founded, as the aforementioned policies are increasing deportations and the number of parent-child separations and transnational families. This violates Article 9 of the Convention on the Rights of the Child which states that children should only be separated from their parents when it is in the best interests of the child, such as in cases of abuse or parental divorce. Zayas (2015) terms these impacts as the creation of US orphans and exiles, depending on whether the deported parents leave the children in the USA or take the children with them. This separation can result in negative emotional and economic outcomes (Dreby, 2012). Immediate effects on families of a deported parent may include the exacerbation or creation of poverty after the loss of the primary breadwinner, loss of a caregiver, and difficulty obtaining basic needs for children (Yoshikawa \& Kalil, 2011; Zayas \& Bradlee, 2014). Children may be placed in foster care following the detention of their parent(s) and may not know their whereabouts. Alternatively, if their parent(s) take them with them when deported, they are then forced to foreign countries where they may never even have visited, creating "exiles," of US citizens in Zayas' term (Zayas, 2015).

The compounded everyday stresses of discrimination, poverty, fear of deportation, and other acculturative stresses strain family relationships over time, reducing the buffer of familism that protects Latino immigrant families during their integration into new environments (Arbona et al., 2010; Bacallao \& Smokowski, 2007). Parental stress is exacerbated by poor or coercive work conditions and unstable employment which contribute further to the decline of familism, socioeconomic well-being, and learning opportunities for children, especially lower enrollment in programs for which they or their children are eligible (Brabeck et al., 2015; Rubio-Hernandez \& Ayón, 2016; Yoshikawa \& Kalil, 2011). In all, these childhood experiences in the family system leave a lasting and cumulative disadvantage that legal access to services (provided by citizenship or documentation) cannot rectify (Enriquez, 2015).

\section{Physical Well-being}

Unauthorized children or children in mixed-status families experience lower levels of physical well-being, typically resulting from lack of access to healthcare, violating Article 24 of the Convention on the Rights of the Child (Javier et al., 2010; García-Pérez, 2013). National numbers show that children of immigrant parents are less likely to be reported in very good or excellent health $(77.3 \%)$ as compared to those in native-born families (83.4\%) (Hernandez \& Cervantes, 2011). Unauthorized children lack access to insurance, public or private, while qualified children may have parents who do not realize they are eligible, do not understand the process to access services, or do not seek access due to fear of deportation (Perreira et al., 2012; Yoshikawa \& Kholoptseva, 2013). Since 1996, there has been a decline in access to healthcare and healthcare insurance coverage for the unauthorized population (Yoshikawa \& Kalil, 2011). Without access to Affordable Care Act (ACA) reforms or public or private sources of insurance, unauthorized immigrants and their families constitute the largest and growing proportion of the uninsured population (Zuckerman et al., 2011). Unauthorized immigrants are far less likely to have private insurance coverage, especially those in low-income families and those with parents working for smaller companies which are less likely to have employer-sponsored coverage (Zuckerman et al., 2011).

Most gains in insurance have been due to enrollment in Medicaid or CHIP programs (Stevens, West-Wright, \& Tsai, 2010; Zuckerman et al., 2011). However, while children may be eligible for these public programs, lack of documentation for all family members can impact enrollment; children in allcitizen families are more likely to have insurance than are either unauthorized children or citizen children in mixedstatus families (Stevens et al., 2010). Eligible US citizen children with immigrant parents are less likely to participate in Medicaid and CHIP than are children with US-born parents (Cardoso et al. 2014). Mixed-status families may avoid Medicaid or other public programs due to fears of exposure or lack of knowledge of eligibility requirements (Watson, 2014).

As discussed, fears related to exposure, as well as experiences of discrimination, deter unauthorized immigrant parents from accessing services for which their citizen children are eligible (Androff et al., 2011; Suárez-Orozco \& Yoshikawa, 2013) while both unauthorized and authorized parents fear authorities; distrust public assistance services; or are confused by, uninformed of, and concerned about the cost of what services exist and may equally underutilize services for their children, compromising children's health and cognitive development (Xu \& Brabeck, 2012; Yoshikawa \& Kalil, 2011). This fear of exposure (of themselves or other family members) and subsequent deportation is a legitimate risk when attempting to access healthcare services and can paralyze parents from entering government buildings or utilizing services (Abrego \& Manjívar 2011; Xu \& Brabeck, 2012). Current policies have created an atmosphere of fear, where unauthorized parents seeking services may put themselves and their families at risk by engaging with service providers (Van Hook et al., 2013). 
A lack of understanding about immigration enforcement policies and services compounds this fear and distrust among immigrant families regarding authorities and service providers (Rhodes et al., 2015). Immigrant families seek to avoid any penalties that would negatively affect future chances of authorization or naturalization, such as being seen as public charges or dependent on the State to support them financially if they access public assistance services (Abrego \& Manjívar 2011; Perreira et al., 2012). Authorized parents may avoid accessing public services for fear that their temporary visas could be revoked (Arbona et al., 2010), while unauthorized parents believe that to be seen as dependent on the State for economic survival would harm their chances of receiving documentation in the future (U.S. Citizenship and Immigration Services [USCIS], 2011). However, to enroll eligible family members in these healthcare programs will not place future risk on the family members to being denied legalization and parents should not fear repercussions (Castañeda \& Melo, 2014).

Cultural protective factors help insulate children from early disparities; e.g., children born to undocumented parents have better prenatal and postnatal outcomes than those born to US citizen counterparts (Ha \& Ybarra, 2014). Immigrant children typically have lower mortality and morbidity risk than US children of immigrants due in part to lower levels of obesity and a healthier diet, but over time this advantage shifts (Enriquez, 2015; Perreira \& Ornelas, 2011; Schmeer, 2012). As summarized by Van Hook et al. (2013), the healthier start declines with age, as early childhood development is significantly impacted by limited English proficiency of parents and/ or children, poverty, and food insecurity resulting in negative physical and mental health outcomes and reduced cognitive skills.

Even when citizen children of immigrant parents have access to formal medical care, their unauthorized siblings and family members typically must do without. Stratified access to care based on legal status may usurp the family dynamic, leading to preferential treatment of citizen children and then resentment within the family system between unauthorized and uninsured members (Abrego \& Manjívar 2011). Parents may choose to avoid services altogether to reduce such dilemmas and risks of perceived favoritism (Perreira et al., 2012). Unauthorized children may be told to avoid becoming sick (Castañeda \& Melo, 2014; Rhodes et al., 2015).

However, alternative care methods and resources within the family system produce resilience and familism and a sense of duty and interdependence, with families exhibiting supportive and adaptive attitudes towards care seeking (Rhodes et al., 2015). Siblings may share prescriptions, using only half of it so another sick sibling can utilize the rest. Sharing medication meets the immediate need of treatment and fosters reciprocity between family members and households, but also leaves a treatment incomplete and less effective (Rhodes et al., 2015).

\section{Psychological Well-being}

There has been limited research conducted to assess the psychosocial implications of growing up in unauthorized or mixed-status homes (Gonzales, Suárez-Orozco, \& DediosSanguineti, 2013). However, the research does appear to indicate that the stress of perpetual fear introduces socioemotional difficulties including depressive, anxious, or posttraumatic stress disorder (PTSD) symptoms (Martinez et al., 2015; Potochnick \& Perreira, 2010). Unauthorized status and its perceived risks are pervasive psychosocial stressors and may be long-lasting, potentially altering children's identity formation as US citizens (Dreby, 2012).

Long-term exposure to such stress has been linked to such psychological consequences as PTSD and decreased cognitive performance, short-term working memory, and impulse control (Plessow, Kiesel, \& Kirschbaum, 2012); it can also have long-term neurobiological and psychological impacts on children and youth and how they react to stress and process emotion (Spear, 2009; Stortelder \& Ploegmakers-Burg, 2010). Zayas (2015) states that the hostile atmosphere towards immigrants in the USA has a "corrosive" effect on children's psychological well-being and that the constant state of worry and fear can cause permanent brain re-structuring due to the ongoing wash of stress hormones.

Childhood development is bolstered by positive and consistent family routines as well as culturally-based practices (Fuller \& García Coll, 2010). Stress from work and unauthorized status can disrupt positive parenting practices and family routines; without these practices, children are at greater risk for emotional and behavioral problems (Landale et al. 2015; Van Hook et al., 2013). Suárez-Orozco and Yoshikawa (2013) explain that fear of authorities and subsequent deportation, low wage and poor work conditions, and overcrowded housing lead to psychological distress, stress, and depression for parents. Parents who work nonstandard work schedules are more likely to have children who have more difficulty in problem-solving and language ability (Han, 2005) and in adolescence are more likely to engage in risky behaviors (Han, Miller, \& Waldfogel, 2010). Han (2005) believes this is likely due to the stresses and exhaustion from a nonstandard schedule and, in later years, lack of supervision (Scheiber, 2015). Children rely on parental emotional and physical availability and the time dedicated to nurturing, supervising, and guiding children (Ayón \& Becerra, 2013), which are linked to greater childhood academic success (Parcel, Dufur, \& Zito, 2010).

Maintaining these family routines is associated with lower levels of internalizing behaviors among Mexican heritage immigrant youth (Landale et al., 2015). In a study of Mexican 
immigrant youths and their parents, Landale et al. (2015) found increased risk levels for children of undocumented Mexican parents in internalizing and externalizing behavior problems compared with those with documented or naturalized citizen mothers. Some youth coming to terms with their unauthorized status externalize their fears, insecurities, and despair through substance abuse and other risk-taking behaviors (Gonzales et al., 2013). Though substance use selfmedicates stress, it can increase negative emotions and precipitate risk-taking behaviors into adulthood.

Other youths may internalize their stress, becoming anxious or sad or showing symptoms of depression, and having difficulty sleeping or eating (Gonzales et al., 2013; Landale et al., 2015). Physical manifestations of stress include the exacerbation of chronic illnesses such as high blood pressure, headaches, or body pain (Gonzales et al., 2013); chronic pain has shown to be exacerbated by immigration-related experiences among immigrant Latino adults (Bui, Doescher, Takeuchi, \& Taylor, 2011). Self-harm and suicidal behavior may result from extreme feelings of isolation, hopelessness, and lack of control over life circumstances; unauthorized youths are vulnerable to the helplessness and social exclusion they experience because of an immigration status they cannot change (Gonzales et al., 2013; Zayas, 2011). As they age and become aware of the limitations their status places on them, the stress, worry, fear, and multiple social exclusions and microaggressions leave these youths with no place to belong, no clear social roles or responsibilities, no sense of meaning, and no sense of future, with suicide the only tangible solution they see (Zayas, 2011).

Parental fears and awareness of status limitations impart similar fears and coping strategies on children of immigrants (Dreby, 2012; Enriquez, 2015), such as avoiding interactions with authority personnel and being fearful of being detained and deported resulting in fewer recreational activities and diminished public engagement, all creating a mental and social isolation that breeds emotional distress (Rhodes et al., 2015; Rubio-Hernandez \& Ayón, 2016). The stresses associated with parental unauthorized status and low-wage work have been linked to lower child cognitive development and lower academic achievement in middle childhood (Suárez-Orozco et al., 2011; Yoshikawa \& Kholoptseva, 2013).

Actual parental detention and deportation have welldocumented negative consequences on children across a range of ages, from the compounded traumas of witnessing the forcible removal of an immigrant parent and losing a caregiver, protector, and familiar home in one fell swoop, or subsequent separations due to sudden parental detainee transfers, to outof-state facilities with no notice to the family or the child (McLeigh, 2010; Valdez et al., 2013). Current immigration policies create sudden family separations lasting weeks, months, or even years. In the past, children were unable to locate their parents or visit with them during their incarceration, and parents commonly lacked adequate legal counsel (Andrapalliyal 2013; Wessler, 2011).

Although the Parental Interests Directive has attempted to promise discretionary action and protection for arrested unauthorized parents with children (U.S. Immigration and Customs Enforcement [ICE], 2013), the impacts of separation on children may still appear, such as in difficulties in eating and sleeping, sadness, anger, guilt, and anxiety, as well as jeopardize their attachment to their parent (Dreby, 2012; Zayas \& Bradlee, 2014). Deportations in the family system negatively affect conduct problems, school attendance, and mental health (Chaudry et al., 2010; Koball et al., 2015).

In the long term, family members of deported individuals exhibit symptoms of social isolation, depression, and suicidal ideation among remaining caregivers, while children show increased anxiety, depression, and PTSD (Yoshikawa \& Kalil, 2011; Zayas, 2015). For immigrant families, the trauma of parental detention is exacerbated over the long term by social stressors such as stigmatization based on race or ethnicity, as well as the impacts of poverty and immigration status on the remaining members of the family (McLeigh, 2010). Intersectionality of identities can affect risk factors; among Latino youth who had immigrant parents or had immigrated themselves at least 5 years ago, depressive symptoms and lower self-esteem were associated with perceived societal discrimination for those in the lowest socioeconomic group (Ríos-Salas \& Larson, 2015).

\section{Educational Outcomes}

One reason parents bring their children to the USA can be to obtain the educational opportunities and the economic mobility the country can provide. Plyler v. Doe (1982) provides unauthorized youth access to free public K-12 education in the USA (Federico, 2013), helping to fulfill Article 28 of the Convention on the Rights of the Child. Additionally, the Family Educational Rights and Privacy Act prohibits schools from releasing student documents to immigration authorities, thus insulating these students from the effects of their, or their parents', immigration status (Olivos \& Mendoza, 2010). Public school is one of the critical environments shaping immigrant youths' identity and socializing them to US society and citizenship (Olivos \& Mendoza, 2010).

Yet, these children too often still lack the resources and support needed to obtain a high school diploma (Federico, 2013). Parental unauthorized status can negatively impact a child's educational attainment, as these children show lower academic achievement in middle childhood (Brabeck et al., 2015) and achieve over a year less in formal schooling (Bean et al., 2015). Academic achievement is mediated by school and social environments with racism; immigrant segregation and isolation; poverty; low expectations from teachers; and 
linguistic, cultural, and familial barriers to inclusion (National Center for Education Statistics [NCES], 2011; Viramontez Anguiano \& Lopez, 2012).

Even before formal schooling begins, educational disadvantages can occur. Citizen children aged 0 to 3 may experience delays in early cognitive development due to the economic hardship, stress, and lack of formal child care stemming from the immigration status of their parent(s) (Yoshikawa, 2012). Formal early childhood programs and educational investments that would support school preparedness, like center-based care, books, and preschool enrollment, are underutilized among Latino children, in particular unauthorized parents, because of lower maternal work rates, few neighborhood options, and reliance on kinship child care (Capps et al., 2016; Fuller \& Kim, 2011; Karoly \& Gonzalez, 2011).

Additionally, working long and, at times unpredictable, hours, receiving low wages, fearing exposure, and experiencing daily marginalization and discrimination all limit to what extent an unauthorized parent can make investments or utilize services that can provide early intervention and exposure to learning (e.g., Head Start or center-based care) and bolster language and cognitive development (Ha \& Ybarra, 2014; Suárez-Orozco \& Yoshikawa, 2013). Thus, unauthorized parents may have difficulty supporting their children in their learning and development.

School performance can also be impacted by the aforementioned psychological impacts of living in a mixed-status family. Childhood mental health or behavioral problems such as depression and hyperactivity have been found to negatively influence performance on standardized math and reading scores in elementary school (Perreira \& Ornelas, 2011). The anxiety arising from the environment of fear and apprehension makes it more difficult for youth to maintain concentration on coursework in high school and college (Potochnick \& Perreira, 2010).

Youth newly arrived to the USA are particularly vulnerable to academic failure and face declines in performance over time due to barriers and social forces (Chavez et al., 2012; Goździak, 2014). Both documented and undocumented Mexican and Central American immigrant youth show significantly lower rates of high school completion and college enrollment than do native Latinos (Greenman \& Hall, 2013). This is due to barriers that exist on the micro, mezzo and macro levels.

On the micro level, children of immigrants enter the education system at different ages, levels of acculturation, and academic preparedness, impacting their rates of school enrollment and attainment. There are those who enter as young children, commonly acculturated and fluent in English; those who enter in middle adolescence who may have had limited prior schooling and face linguistic barriers to success (Hernández et al., 2010); and those who will never enter school because of their age of entry to the USA (usually 14 and older) (Goździak, 2014) and the expectation that they become employed to support themselves in the USA (Clotfelter et al. 2012).

Within the family environment, parents' poor work conditions are associated with poorer academic achievement in middle and high school children (Suárez-Orozco et al., 2011). Familial poverty due to low wages and lack of benefit eligibility creates situations of food and housing insecurity (Viramontez Anguiano \& Lopez, 2012). In a mixed-status family struggling to pay rent, parents may invite renters, extended family, or friends to share living space, thereby limiting the study space available for children and increasing a child's family responsibilities such as helping elders, cooking, or translating for family and friends (Bacallao \& Smokowski 2007; Gleeson \& Gonzales, 2012; Suárez-Orozco et al., 2011).

Immigrant parents tend to have less education, with undocumented immigrants having even fewer years of schooling than documented immigrant parents, and lack the necessary knowledge of the US education system to navigate it successfully (Goździak, 2014; Viramontez Anguiano \& Lopez, 2012), a lack of familiarity which impacts youths themselves as they attempt to navigate high school and higher education on their own (Contreras, 2009). Thus, having better educated parents or having parents who legalize are protective factors against dropping out of school (Greenman \& Hall, 2013). Graduating from high school is integral to the advancement of children of immigrants in the USA (Goździak, 2014).

The compounded vulnerabilities of language, socioeconomic status, immigration status, and race/ethnicity constrict the opportunities for many Latinos and limit parental engagement in school, a protective factor for academic success (Olivos \& Mendoza, 2010; Parcel et al., 2010). School involvement can be challenging for immigrant families, to the extent that they are excluded from active participation by the school environment through their linguistic, social, and timerelated barriers to involvement, including fears of exposure and the financial need to work (Olivos \& Mendoza, 2010). Language barriers, stigmatization, microaggressions, fear of exposure, and lack of familiarity with the education system negatively affect parental engagement (Olivos \& Mendoza, 2010). This can be eased through the use of bilingual staff who are informed about immigrants' rights and are able to build trusting and positive relationships with parents which increase parental involvement in their children's schools (Valdez et al., 2013; Van Hook et al., 2013).

On the macro level, the quality of the school environment makes a world of difference for unauthorized youths. They may suffer from an under-resourced school environment or, in contrast, be positively tracked into smaller classes and offered support (Gleeson \& Gonzales, 2012). Within these environments, some students will be positively supported to 
graduate high school and move on to college, but those lacking this supportive network - without positive teacher or mentor relationships, one-on-one teacher interactions, or classroom support-will commonly drop out of high school (Enriquez, 2011; Gonzales et al., 2013). Having positive role models and mentors bolsters academic attainment, as trusting peers and supportive partners mitigates the discrimination and stress involved and provided support and resources (Contreras, 2009). Students lacking these supports may be forced to prove themselves academically to their teachers and administrators, at times fighting to prove their English fluency and academic skills (Hernández et al., 2010). Unauthorized immigrant students may experience discrimination, racism, and bullying at the hands of teachers, administrators, and peers, negatively impacting their ability to succeed (Enriquez, 2011; Goździak, 2014).

\section{Conclusion}

There are numerous social, material, and psychological costs associated with lacking authorized status in the USA, which violate children's rights in myriad ways. Due to the operating political and social policies, a disenfranchised underclass has begun to develop without the means for full social and political integration into US society. Such integration depends on the ability of immigrants and subsequent generations to participate in schools and in the labor market, as well as methods for mobility to achieve parity with the native-born US majority (Waters \& Pineau, 2016). Being unauthorized or having unauthorized parents substantially impairs development long into the future, contributing to poor academic, health, and social outcomes by restricting access to early learning opportunities and formal child care, postsecondary school, formal employment, and thus, activities necessary to participate fully in social, political, and economic life.

A hostile social and political climate combined with cumulative social, economic, and interpersonal stresses takes its toll on the mental health of children and youth, as well as their parents. Though undocumented families are strong and resilient, exhibiting high levels of commitment to the learning of their children (Yoshikawa \& Kalil, 2011), unauthorized status is a tangible risk to the well-being of children and youth and remains a formidable barrier to integration and participation in US society, whether the child is a citizen or not. The Deferred Action for Childhood Arrivals (DACA) program, with its temporary relief from fear of deportation and ability to work, and its companion Deferred Action for Parental Accountability (DAPA) will help alleviate some of these concerns. However, these are only temporary programs and permanent action must be taken.

These consequences have a variety of implications for social workers. Regardless of the primary population with whom they work, it is likely that social workers will be engaged with those who are foreign-born, including those who lack legal status or are members of a mixed-status family. Additionally, due to the conflation of identities, all of those who are Hispanic are vulnerable to the negative sentiment against those of their ethnicity, and the microaggressions and discrimination can impact them in a variety of ways, as outlined in this paper.

Therefore, it is the responsibility of social workers to help improve this situation on all system levels: micro, mezzo, and macro. We must work to help alleviate and reduce the impact on individual children and assist their families. However, we must also work on the broader system level to create policies that promote positive child development and help actualize the rights guaranteed to them. We need to work to increase access to medical care, help to ease psychological distress, and create empowering school environments. This will create a better world for the children, but also for society.

\section{References}

Abrego, L. J., \& Gonzales, R. G. (2010). Blocked paths, uncertain futures: the postsecondary education and labor market prospects of undocumented Latino youth. Journal of Education for Students Placed at Risk, 15(1-2), 144-157.

Abrego, L. J., \& Manjívar, C. (2011). Immigrant Latina mothers as targets of legal violence. International Journal of Sociology of the Family, $37(1), 9-26$.

Alvarez Gutiérrez, L. (2013). Costo alto de política anti-inmigrante sobre la familia y educación: the adverse consequences of anti-Latino immigration laws. Theory into Practice, 52, 169-179. doi:10. 1080/00405841.2013.804308

Andrapalliyal, V. (2013). The CPS took my baby away: threats to immigrant parental rights and a proposed federal solution. Harvard Law \& Policy Review, 7, 173-197.

Androff, D. K., Ayón, C., Becerra, D., Gurrola, M., Salas, L., Krysik, J...\& Segal. E. (2011). U.S. immigration policy and immigrant children's well-being: the impact of policy shifts. Journal of Social Welfare, 38(1), 77-98.

Arbona, C., Olvera, N., Rodriguez, N., Hagan, J., Linares, A., \& Wiesner, M. (2010). Acculturative stress among documented and undocumented Latino immigrants in the United States. Hispanic Journal of Behavioral Sciences, 32, 362-384. doi:10.1177/ 0739986310373210

Ayón, C., \& Becerra, D. (2013). Mexican immigrant families under siege: the impact of anti-immigrant policies, discrimination, and the economic crisis. Advances in Social Work, 14(1), 206-228.

Bacallao, M. L., \& Smokowski, P. R. (2007). The costs of getting ahead: Mexican family system changes after immigration. Family Relationship, 56(1), 52-66.

Bean, F. D., Brown, S. K., \& Bachmeier, J. D. (2015). Parents without papers: the progress and pitfalls of Mexican American integration. New York, NY: Russell Sage.

Brabeck, K. M., Sibley, E., Taubin, P., \& Murcia, A. (2015). The influence of immigrant parent legal status on US-born children's academic abilities: the moderating effects of social service use. Applied Developmental Science [published online before print]. doi:10. 1080/10888691.2015.1114420 
Bui, Q., Doescher, M., Takeuchi, D., \& Taylor, V. (2011). Immigration, acculturation and chronic back and next problems among LatinoAmericans. Journal of Immigrant and Minority Health, 13(2), 194 201. doi:10.1007/s10903-010-9371-3

Capps, R., Rosenblum. M. R., Rodriguez, C., \& Chishti, M. (2011). Delegation and divergence: a study of $287(\mathrm{~g})$ state and local immigration enforcement. Migration Policy Institute. Retrieved from http://www.migrationpolicy.net

Capps, R., Fix, M., \& Zong, J. (2016). A profile of U.S. children with unauthorized immigrant parents. Migration Policy Institute. Retrieved from http://www.migrationpolicy.net

Cardoso, J. B., Dettlaff, A. J., Finno-Velasquez, M., Scott, J., \& Faulkner, M. (2014). Nativity and immigration status among Latino families involved in the child welfare system: characteristics, risk and maltreatment. Children and Youth Services Review, 44, 189-200.

Castañeda, H., \& Melo, M. A. (2014). Health care access for Latino mixed-status families: barriers, strategies, and implications for reform. American Behavioral Scientist, 58(14), 1891-1909. doi:10. 1177/0002764214550290

Chaudry, A., Capps, R., Pedroza, J. M., Castañeda, R. M., Santos, R. \& Scott, M. M. (2010). Facing our future: children in the aftermath of immigration enforcement. The Urban Institute \& The National Council of La Raza (NCLR). Retrieved from http://www.urban.org

Chavez, J. M., Lopez, A., Englebrecht, C. M., \& Viramontez Anguiano, R. P. (2012). Sufren los niños: exploring the impact of unauthorized immigration status on children's well-being. Family Court Review, 50(4), 638-649. doi:10.1111/j.1744-1617.2012.01482.x

Clotfelter, C. T., Ladd, H. F., \& Vigdor, J. L. (2012). New destinations, new trajectories? The educational attainment and persistence of Hispanic youth in North Carolina. Child Development, 83(5), $1608-1622$

Contreras, F. E. (2009). Sin papeles y rompiendo barreras: Latina/o students and the challenges of persisting in college [Without papers and breaking barriers]. Harvard Educational Review, 79, 610-632.

Donato, K. M., \& Rodriguez, L. A. (2014). Police arrests in a time of uncertainty: the impact of $287(\mathrm{~g})$ on arrests in a new immigrant gateway. American Behavioral Scientist, 58(13), 1696-1722.

Dreby, J. (2012). The burden of deportation on children in Mexican immigrant families. Journal of Marriage and Family, 74, 829845. doi:10.1111/j.1741-3737.2012.00989.x

Dreby, J. (2015). Everyday illegal: when policies undermine immigrant families. Oakland, CA: University of California.

Enriquez, L. E. (2011). "Because we feel the pressure and we also feel the support": examining the educational success of undocumented immigrant Latina/o students. Harvard Educational Review, 81, 476499.

Enriquez, L. E. (2015). Multigenerational punishment: shared experiences of undocumented immigration status within mixed-status families. Journal of Marriage and Family, 77, 939-953. doi:10.1111/ jomf. 12196

Federico, R. (2013). Lifting the "lamp beside the golden door": an argument for immigration reform, advocacy, and transformation through testimonios. Berkeley La Raza Law Journal, 23, 3-34.

Flores, R. D. (2014). Living in the eye of the storm: how did Hazleton's restrictive immigration ordinance affect local interethnic relations? American Behavioral Scientist, 58(13), 1743-1763.

Fuller, B., \& García Coll, C. (2010). Learning from Latinos: contexts, families and child development in motion. Developmental Psychology, 46(3), 559-565. doi:10.1037/a0019412

Fuller, B., \& Kim, A. Y. (2011). Latino access to preschool stalls after earlier gains: Certain to harden achievement gaps, erode workforce quality. Berkeley: University of California, Berkeley, Institute of Human Development, New Journalism on Latino Children.
Retrieved from http://ihd.berkeley.edu/Latino preschool decline NOLA-NJLC-Brief-2011-FINAL.pdf.

García-Pérez, M. (2013). Health care usage and health status of immigrant children: the effects of nativity versus citizenship. American Economic Review: Papers \& Proceedings, 103(3), 412-417. doi:10. 1257/aer.103.3.412

Gleeson, S., \& Gonzales, R. G. (2012). When do papers matter? An institutional analysis of undocumented life in the United States. International Migration, 50(4), 1-19. doi:10.1111/j.1468-2435. 2011.00726.x

Gonzales, R. G., \& Chavez, L. R. (2012). "Awakening to a nightmare": abjectivity and illegality in the lives of undocumented 1.5-generation Latino immigrants in the United States. Current Anthropology, 53(3), 255-281.

Gonzales, R. G., Suárez-Orozco, C., \& Dedios-Sanguineti, M. C. (2013). No place to belong: contextualizing concepts of mental health among undocumented immigrant youth in the United States. American Behavioral Scientist, 57(8), 1174-1199. doi:10.1177/ 0002764213487349

Goździak, E. M. (2014). To dream or not to dream: the effects of immigration status, discrimination, and parental influence on Latino children's access to education. Migration Studies, 2(3), 392-414. doi: 10.1093/migration/mnu021

Greenman, E., \& Hall, M. (2013). Legal status and educational transitions for Mexican and Central American immigrant youth. Social Forces, 91(4), 1475-1498. doi:10.1093/sf/sot040

Ha, Y., \& Ybarra, M. (2014). The role of parental immigration status in Latino families' child care selection. Children and Youth Services Review, 47, 342-351.

Hagan, J., Castro, B., \& Rodriguez, N. (2010). The effects of U.S. deportation policies on immigrant families and communities: cross-border perspectives. North Carolina Law Review, 88, 1799-1824.

Han, W. (2005). Maternal nonstandard work schedules and child cognitive outcomes. Child Development, 76(1), 137-154. doi:10.1111/j. 1467-8624.2005.00835.x

Han, W., Miller, D. P., \& Waldfogel, J. (2010). Parental work schedules and adolescent risky behaviors. Developmental Psychology, 46(5), 1245-1267. doi:10.1037/a0020178

Hardy, L. J., Getrich, C. M., Quezada, J. C., Guay, A., Michalowski, R. J., \& Henley, E. (2012). A call for further research on the impact of state-level immigration policies on public health. American Journal of Public Health, 102(7), 1250-1254. doi:10.2105/AJPH.2011. 300541

Hernandez, D. J., \& Cervantes, W. D. (2011). Children in immigrant families: ensuring opportunity for every child in America. Foundation for Child Development. Retrieved from http://fcd-us. org/sites/default/files/First $\% 20$ Focus $\% 20-\% 20$ Children $\% 20$ in $\% 20$ Immigrant $\% 20$ Families.pdf

Hernández, S., Hernández, I., Gadson, R., Huftalin, D., Ortiz, A. M., White, M. C., \& Yocum-Gaffney, D. (2010). Sharing their secrets: undocumented students' personal stories of fear, drive, and survival. New Directions for Student Services, 6784. doi: $10.1002 /$ ss.368

Javier, J. R., Huffman, L. C., Mendoza, F. S., \& Wise, P. H. (2010). Children with special health care needs: how immigrant status is related to health care access, health care utilization, and health status. Maternal and Child Health Journal, 14, 567-579. doi:10.1007/ s10995-009-0487-9

Karoly, L. A., \& Gonzalez, G. C. (2011). Early care and education for children in immigrant families. The Future of Children, 21(1), 71102.

Koball, H., Capps, R., Hooker, S., Perreira, K., Campetella, A., Pedroza, J. M...Huerta, S. (2015). Health and social service needs of UScitizen children with detained or deported immigrant parents. Migration Policy Institute \& The Urban Institute. Retrieved from http://www.migrationpolicy.org 
Landale, N. S., Hardie, J. H., Oropesa, R. S., \& Hillemeier, M. M. (2015). Behavioral functioning among Mexican-origin children: does parental legal status matter? Journal of Health and Social Behavior, 56(1), $2-18$.

Manjívar, C., \& Abrego, L. J. (2012). Legal violence: immigration law and the lives of Central American immigrants. American Journal of Sociology, 117(5), 1380-1421.

Martinez, O., Wu, E., Sandfort, T., Dodge, B., Carballo-Dieguez, C., Pinto, R... Chavez-Baray, S. (2015). Evaluating the impact of immigration policies on health status among undocumented immigrants: a systematic review. Journal of Immigrant Minority Health, 17, 947-970. doi. 10.1007/s10903-013-9968-4

McLeigh, J. D. (2010). How do Immigration and Customs Enforcement (ICE) practices affect the mental health of children? American Journal of Orthopsychiatry, 80(1), 96-100.

National Center for Education Statistics. (2011). The condition of education 2011. Retrieved from http://nces.ed.gov/fastfacts/display.asp? $\mathrm{id}=16$

Olivos, E. M., \& Mendoza, M. (2010). Immigration and educational inequality: examining Latino immigrant parents' engagement in U.S. public schools. Journal for Immigrant \& Refugee Studies, 8(3), 339-357. doi:10.1080/15562948.2010.501301

Parcel, T. L., Dufur, M. J., \& Zito, R. C. (2010). Capital at home and at school: a review and synthesis. Journal of Marriage and Family, 72(4), 828-846. doi:10.1111/j.1741-3737.2010.00733.x

Passel, J. S, \& Cohn, D. (2014). Birthplaces of U.S. unauthorized immigrants. Pew Research Center. Retrieved from http://www. pewhispanic.org/2014/11/18/chapter-2-birthplaces-of-u-sunauthorized-immigrants/

Perreira, K. M., \& Ornelas, I. J. (2011). The physical and psychological well-being of immigrant children. The Future of Children, 21(1), 195-218.

Perreira, K. M., Crosnoe, R., Fortuny, K., Pedroza, J. Ulvestad, K., Weiland, C...\& Chaudry, A. (2012). Barriers to immigrants' access to health and human services programs. ASPE Issue Brief. Retrieved from $\mathrm{http} / / /$ aspe.hhs.gov/hsp/11/ImmigrantAccess/index.shtml

Plessow, F., Kiesel, A., \& Kirschbaum, C. (2012). The stressed prefrontal cortex and goal-directed behavior: acute psychosocial stress impairs the flexible implementation of task goals. Experimental Brain Research, 216(3), 397-408. doi:10.1007/s00221-011-2943-1

Potochnick, S. R., \& Perreira, K. M. (2010). Depression and anxiety among first-generation immigrant Latino youth: key correlates and implications for future research. Journal of Nervous and Mental Disease, 198(7), 470-477. doi:10.1097/NMD.0b013e3181e4ce24

Rhodes, S. D., Mann, L., Simán, F. M., Song, E., Alonzo, J., Downs, M., ...Hall, M. A. (2015). The impact of local immigration enforcement policies on the health of immigrant Hispanics/Latinos in the United States. American Journal of Public Health, 105(2), 329-337.

Ríos-Salas, V., \& Larson, A. (2015). Perceived discrimination, socioeconomic status, and mental health among Latino adolescents in US immigrant families. Children and Youth Services Review, 56, 116125 .

Rubio-Hernandez, S., \& Ayón, C. (2016). Pobrecitos los niños: the emotional impact of anti-immigration policies on Latino children. Children and Youth Services, 60, 20-26.

Scheiber, N. (2015, August 12). The perils of ever-changing work schedules extend to children's well-being. The New York Times. Retrieved from http://www.nytimes.com

Schmeer, K. K. (2012). Early childhood economic disadvantage and the health of Hispanic children. Social Science and Medicine, 75(8), 1523-30. doi:10.1016/j.socscimed.2012.05.031

Spear, L. P. (2009). Heightened stress responsivity and emotional reactivity during pubertal maturation, Implications for psychopathology. Developmental Psychopathology, 21(1), 87-97. doi:10.1017/ S095457909000066
Stevens, G. D., West-Wright, C. N., \& Tsai, K. (2010). Health insurance and access to care for families with young children in California, 2001-2005: differences by immigration status. Journal of Immigrant Minority Health, 12, 273-281. doi:10.1007/s10903008-9185-8

Stortelder, F., \& Ploegmakers-Burg, M. (2010). Adolescence and the reorganization of infant development: a neuropsychoanalytic model. Journal of the American Academy Psychoanalysis and Dynamic Psychiatry, 38(3), 503-31. doi: 10.1521/jaap.2010.38.3.503

Suárez-Orozco, C., \& Yoshikawa, H. (2013). Undocumented status: implications for child development, policy, and ethical research. New Directions for Child and Adolescent Development, 141, 61-78.

Suárez-Orozco, C., Yoshikawa, H., Teranishi, R. T., \& Suárez-Orozco, M. M. (2011). Growing up in the shadows: the developmental implications of unauthorized status. Harvard Educational Review, 81(3), 438-473.

U.S. Citizenship and Immigration Services [USCIS] (2011). Public charge fact sheet. Retrieved from http://www.uscis.gov/news/factsheets/public-charge-fact-sheet

U.S. Immigration and Customs Enforcement (ICE). (2013). Facilitating parental interests in the course of civil immigration enforcement activities. Retrieved from http://www.ice.gov

Valdez, C. R., Padilla, B., \& Valentine, J. L. (2013). Consequences of Arizona's immigration policy on social capital among Mexican mothers with unauthorized immigration status. Hispanic Journal of Behavioral Sciences, 35(3), 303-322. doi:10.1177/ 0739986313488312

Van Hook, J., Landale, N. S., \& Hillemeier, M. M. (2013). Is the United States bad for children's health?: risk and resilience among young children of immigrants. Migration Policy Institute. Retrieved from http://www.migrationpolicy.org

Viramontez Anguiano, R. P., \& Lopez, A. (2012). El miedo y el hambre: understanding the familial, social, and education realities of undocumented Latino families in North Central Indiana. Journal of Family Social Work, 15, 321-336. doi:10.1080/10522158.2012.695324

Viruell-Fuentes, E. A., Miranda, P. Y., \& Abdulrahim, S. (2012). More than culture: structural racism, intersectionality theory, and immigrant health. Social Science \& Medicine, 75(12), 2099-2106. doi: 10.1016/j.socscimed.2011.12.037

Warren, R. (2016). US undocumented population drops below 11 million in 2014, with continued declines in the Mexican undocumented population. Journal on Migration and Human Security, 4(1), 1-15.

Waters, M. C., \& Pineau, M. G. (2016). The integration of immigrants into American society. Washington, D.C.: The National Academies Press.

Watson, T. (2014). Inside the refrigerator: immigration enforcement and chilling in immigrant Medicaid participation. American Economic Journal: Economic Policy, 6(3), 313-38.

Wessler, S. F. (2011). Shattered families: the perilous intersection of immigration enforcement and the child welfare system. Applied Research Center. Retrieved from https://www.raceforward.org/ research/reports/shattered-families

$\mathrm{Xu}$, Q., \& Brabeck, K. (2012). Service utilization for Latino children in mixed-status families. Social Work Research, 36(3), 209-221.

Yoshikawa, H. (2012). Immigrants raising citizens: undocumented parents and their young children. New York, NY: Russell Sage Foundation.

Yoshikawa, H., \& Kalil, A. (2011). The effects of parental undocumented status on the developmental contexts of young children in immigrant families. Development Perspectives, 5(4), 291-297. doi:10.1111/j. 1750-8606.2011.00204.x

Yoshikawa, H., \& Kholoptseva, J. (2013). Unauthorized immigrant parents and their children's development: a summary of the evidence. 
Migration Policy Institute. Retrieved from http://www. migrationpolicy.org

Zayas, L. (2011). Latinas attempting suicide: when cultures, families and daughters collide. New York, NY: Oxford University Press.

Zayas, L. (2015). Forgotten citizens: deportation, children, and the making of American exiles and orphans. New York, NY: Oxford University Press.
Zayas, L. H., \& Bradlee, M. H. (2014). Exiling children, creating orphans: when immigration policies hurt citizens. Social Work, 59(2), 167-175. doi:10.1093/sw/swu004

Zuckerman, S., Waidmann, T. A., \& Lawton, E. (2011). Undocumented immigrants, left out of health reform, likely to continue to grow as share of the uninsured. Health Affairs, 30(10), 1997-2004. 